\title{
The Shifting of Ecotourism in Tegal Regency
}

\author{
Siswo Harsono \\ \{siswo.harsono@gmail.com\} \\ Department of English, Faculty of Humanities, Diponegoro University \\ Jl. Prof. Soedarto, S.H. Undip Tembalang, Semarang, Central Java - Indonesia, 50275
}

\begin{abstract}
This research deals with the shifting of ecotourism in Tegal Regency, Central Java, Indonesia. The purpose of this research is to investigate the shifting of ecotourism especially in Tegal Regency. This research uses ecotourism theory, and applies library research methods to collect informative data about ecotourism and fieldwork to collect data by interviewing the informants of tourism in Tegal Regency. By applying the theory and the methods, it is found that Tegal Regency has mountain ecotourism, park ecotourism, river ecotourism, lake ecotourism, and beach ecotourism. On the one hand, ecotourism relates to natural tourism objects; on the other hands, it relates to sport tourism and cultural tourism. The ecotourism in Tegal Regency becomes the prime tourism attractions that are able to attract local, domestic, and foreign tourists.
\end{abstract}

Keywords: ecotourism; mountain eceotourism; river ecotourism; lake ecotourism; beach ecotourism.

\section{Introduction}

This paper is the result of research on ecotourism in Tegal Regency. Ecotourism in Tegal Regency is spread in several districts. Not all sub-districts have natural attractions. This study aims to inventory, classify, and examine changes that have occurred in ecotourism in Tegal Regency. Inventory is done to record how many ecotourism objects in Tegal Regency. Classification is done to classify the types of ecotourism. The research on shifting is carried out to investigate how ecotourism in Tegal Regency has changed.

\section{Method}

Ecotourism may be a sort of tourism impressed primarily by the explanation of a vicinity, as well as its native cultures and wherever a typical theme in most definitions of touristry is accountable tourism in natural areas ready to facilitate conservation objectives and able to promote environmentally property development and conservation. ${ }^{[1]}$ This research uses library research methods and field work. Library research methods are conducted to explore information about ecotourism in Tegal Regency. Field work is conducted to explore the information by conducting observations and interviews with local informants.

\section{Results and Discussion}

Tegal Regency has 18 districts: Keramat, Suradadi, Warureja, Dukuhturi, Talang, Tarub, Adiwerna, Pangkah, Kedungbanteng, Dukuhwaru, Slawi, Pagerbarang, Lebaksiu, Jatinegara, Margasari, Balapulang, Bumijawa and Bojong.[2] 
However, not all districts of Tegal Regency have ecotourism objects. Up to now there is no ecotourism object in five districts such as Warureja, Dukuhturi, Adiwerna, Dukuhwaru and Pagerbarang.[3]

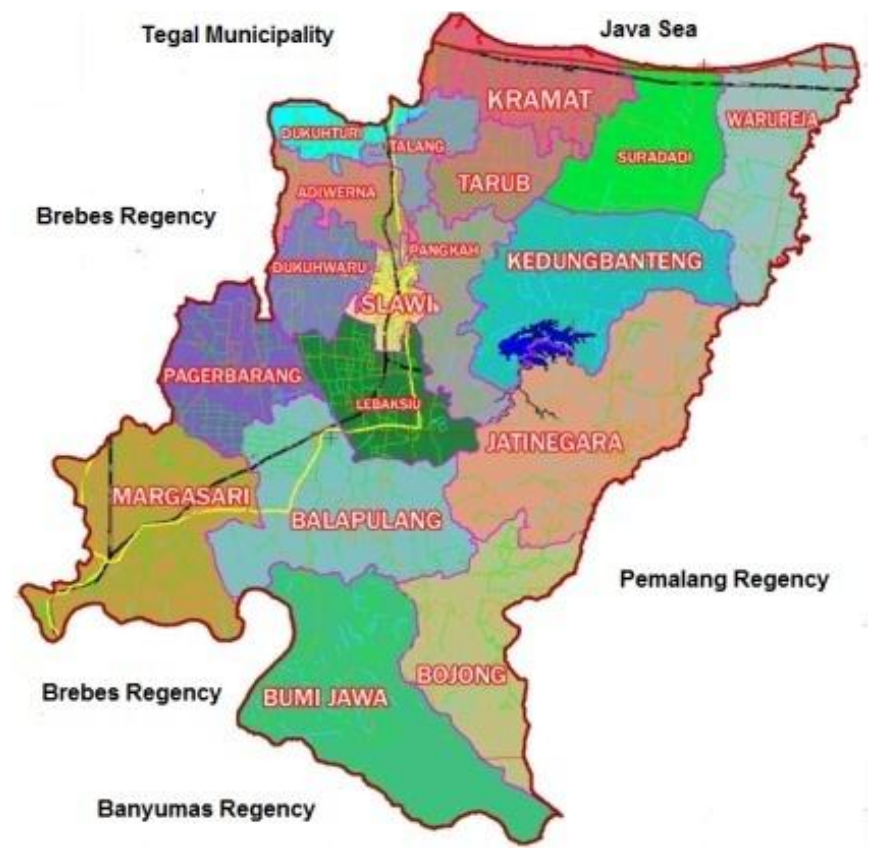

Fig. 1. Tegal Regency Map[4]

Ecotourism objects in Keramat district are Maribaya jasmine field, Karang jeruk conservation, Larangan beach, and Dampyak beach. Ecotourism objects in Suradadi district are Purwahamba indah beach and Suradadi beach. Talang district has Red bridge ecotourism object. Tarub district has Kabukan reservoir. Pangkah district has Cacaban reservoir. Kedungbanteng district has Sigowang waterfall. Slawi district has Yogya Waterboom, Poci park, and Antelope breeding. Lebaksiu district has Mt. Tanjung and Kaliwadas waterfall. Jatinegara district has Wrayan view. Margasari district has Beko lake and Seven waterfalls. Bojong district has Karangpring, Banyumudal springs, and Batunyana hill. Ecotourism objects in Balapulang district are Batu Agung hill, Danawarih suspension bridge, Rangkok hill, Lawet cave, and WKJ Kalibakung.

Ecotourism objects in Bumijawa district are Guci hot water, Guciku hot waterboom, Sulaku park, Tea field Agrotourism, Baper hill, Cepu hill, Star hill, Guci forest tourism, Cantel waterfall, Jejeg waterfall, Luhur waterfall, Twin waterfall, Bride waterfall, Cawitali bride waterfall, Princess waterfall, Sentul waterfall, Gung waterfall, Jedor waterfall, Kaliawu waterfall, Kalidiang waterfall, Kaliputih waterfall, Monkey waterfall, Longan waterfall, Sigayong waterfall, Cempaka lake, Kaliwangun lake, and Kemadu lake.

\subsection{Ecotourism classification}


Ecotourism objects in Tegal Regency can be classified into mountain ecotourism, park ecotourism, river ecotourism, lake ecotourism, and coastal ecotourism. Mountain ecotourism is described as tourism which does not reduce the natural and cultural settings of the mountainous region, provides economic, environmental and social benefits for the mountainous people (local residents), and offers high-quality expertise to guests. ${ }^{[6]}$ Mountain ecotourism in Tegal Regency consists of Baper hill, Cepu hill, Star hill, Batunyana hill, Guci forest ecotourism, Karangpring, Batu agung hill, Rangkok hill, Tea field Agrotourism, WKJ Kalibakung, Mt. Tanjung, Wrayan view, Antelope breeding, and Maribaya jasmin field.

Amusement parks as products include three things that contribute to each tangible and intangible part of the amusement park as factory-made merchandise and destinations. Regarding management, competitive methods, tourist trade and inventive industries are classified as amusement parks as industries. Regarding the design of the city and also the original economy it is classified as an amusement park as a city infrastructure. The park seems to not only complete the functions of the city but is part of the city's infrastructure. ${ }^{[7]}$ Park ecotourism in Tegal Regency consists of Poci park and Sulaku Park.

River is a significant ecotourism resource in providing spectacular settings, recreational opportunities, urban district landscapes in several centers of ecotourism business interests, transportation methods and water supplies that are important for human consumption. Beautiful rivers in the world have long made tourists interested and even in previous days provided a backcloth for traveling. It is clear that except for mountains, beaches, caves, lakes and different ecotourism businesses, rivers are one of the most attractive ecotourism business resources to choose from. ${ }^{[8]}$ River ecotourism in Tegal Regency consists of Guci hot water, Guciku Hot Waterboom, Yogya waterboom, Cantel waterfall, Jejeg waterfall, Luhur waterfall, Twin waterfall, Bride waterfall, Cawitali bride waterfall, Princess waterfall, Sentul waterfall, Gung waterfall, Jedor waterfall, Kaliawu waterfall, Kalidiang waterfall, Kaliputih waterfall, Monkey waterfall, Longan waterfall, Sigayong waterfall, Kaliwadas waterfall, Seven waterfalls, Sigowang waterfall, Lawet cave, Red bridge, and Danawarih suspension bridge.

Lake is described as a reservoir of fresh water which is usually surrounded by land and without direct access to the sea. A lake can be isolated, without direct direct water input and often without direct output. Lakes may occur anywhere in the river flow. There are lakes like water lakes that have no flow contribution but are supported by the entry of several small tributaries, especially from the flow and entry of groundwater. The lake is famous for its high value to the indigenous people. ${ }^{[9]}$ Lake ecotourism in Tegal Regency consists of Cempaka lake, Kaliwangun lake, Kemadu lake, Beko lake, Kabukan reservoir, Banyumudal springs, and Cacaban reservoir.

Beach ecotourism is the earliest trendy tourism style and principal of an ecotourism business that is usually regarded as the result of the inevitable attraction to the coast, but connections are one where business and leisure are an integral part of the need for coastal formation. As an ecotourism destination, this beach fits in with contemporary business talent which can partly occur because the coast is an attractive vacation home after defeating the danger sentiment and oddity through gradual rediscovery as a beach resort and playground for pleasure. ${ }^{[10]}$ Beach ecotourism in Tegal Regency consists of Karang jeruk conservation, Larangan beach, Dampyak beach, Purin beach, and Suradadi beach.

Tegal Regency has 53 ecotourism objects that can be classified into mountain ecotourism 26,41\%, park ecotourism 3,77\%, river ecotourism 47,16\%, lake ecotourism $13,20 \%$, and beach ecotourism $9,43 \%$. Ecotourism in Tegal Regency is dominated by river ecotourism $47,16 \%$. 
Table 1. Percentage of Ecotourism types in Tegal Regency

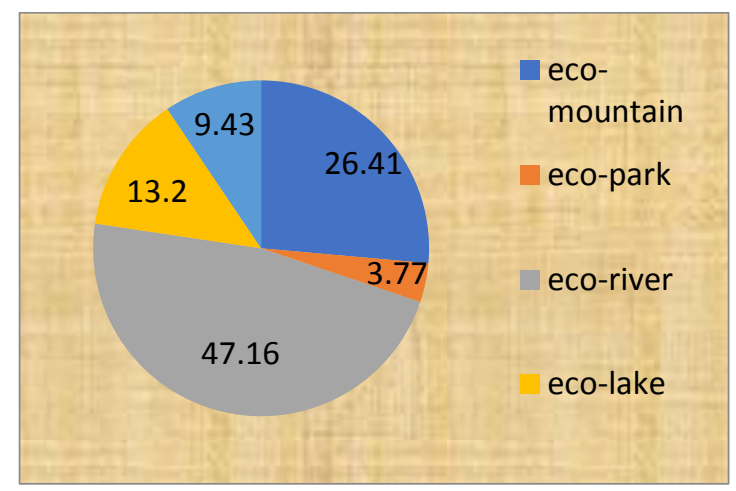

\subsection{Ecotourism shiftings}

The shiftings of ecotourism in Tegal Regency occur in several tourist attractions which include mountain ecotourism, river ecotourism, lake ecotourism, and beach ecotourism.

The shiftings in mountain ecotourism take place at Guci forest ecotourism. These shiftings occur because of a combination with sport tourism such as outbound, flying fox, pintball play, hiking, etc. Besides, there is a shifting of ecocultural tourism called ruwat bumi of Guci. The shiftings in the Baper hill occur because it is used as campsites.

The shiftings in river ecotourism take place at the Guci Hot Water Bathing and Guci Hot Waterboom. These shiftings occur because the use of hot water is not only to be a bathing place, but also a place for playing hot water and swiming. The river ecotourism that has shifted is Sigeyong waterfall, where the flow below becomes a place for mini rafting and tubing.

The shiftings in lake ecotourism occur at Beko lake, Cacaban reservoar, and Cempaka lake. At first Beko lake was a former excavation using a tractor called beko. Then the excavation of the land is flooded like a lake, and is called Beko lake.The shiftings in Cacaban reservoar occur in boathing and ecocultural tourism called sedekah bumi. At first Cempaka lake was a source of water used by local residents to irrigate the surrounding fields; then the lake is managed as one of the beautiful natural attractions. On the outskirts of the lake there are several gazebos and swan boats to surround the lake.

The shiftings to the beach ecotourism occur at Purwahamba Indah Beach. The beach has become a beautiful water recreation area.

\section{Conclusion}

Tegal Regency has 53 ecotourism objects that can be classified into mountain ecotourism, park ecotourism, river ecotourism, lake ecotourism, and beach ecotourism. Ecotourism in 
Tegal Regency is dominated by river ecotourism, especially in Bumijawa District. Most of the ecotourism objects are still natural; and a small part has undergone a shifting due to a combination of sports ecotourism and ecocultural tourism. These changes provide added value to local ecotourism. The combination of ecotourism with sports tourism mutualistic symbiosis occurs so that ecotourism not only presents natural beauty, but also presents healthy sport games. This phenomenon leads to be an ecosport tourism. Similarly, the combination of ecotourism with cultural tourism provides added value to the local culture in carrying out tourist attractions pleasing to local natural attractions. In other words, there are shiftings from pure ecotourism becomes ecosport tourism and ecocultural tourism.

Acknowledgments. I thank to Tourism Agency of Tegal Regency, Culture Agency of Tegal Regency, local informants ecotourism in Tegal Regency, and the research team in which I am a member.

\section{References}

[1] Bulatović, Jelisavka and Rajović, Goran. "Some Aspects of Eco Tourism with View to Montenegro: Overview." Journal of Advocacy, Research and Education, 4(2), 96-111, (2017).

[2] Nanda. "39 Tempat Wisata Favorit di Tegal Jawa Tengah yang Wajib Dikunjungi." < https://tempatwisataseru.com/tempat-wisata-di-tegal/>.

[3] Aneka wisata. "35 Tempat Wisata di Tegal Terbaru yang Bagus dan Hits.” 27 September 2016. <https://www.anekawisata.com/tempat-wisata-di-tegal-terbaru-yang-bagus-danhits.html.

[4] "Peta Kecamatan Kabupaten Tegal." 19 September 2017. <https://www.sejarahnegara.com/2017/09/peta-kabupaten-tegal.html>.

[5] Wisata Tegal. 2013. <https://wisatategal.com/index.php>.

[6] Nepal, Sanjay K. "Mountain Ecotourism and Sustainable Development." Mountain Research and Development, 22(2):104-109 (2002).

[7] Zhang, Wen and Shan, Shilian. "The theme park industry in China: A research review." Cogent Social Sciences, 2: 1210718 (2016).

[8] Hafizudin, Mohamad and others. "River Tourism: A Potential in Pergau River, Jeli, Kelantan.” Journal of Tourism, Hospitality and Sports - An Open Access International Journal Vol.1 (2013).

[9] Asyraf, M. K. M., Nor'Aini Y. and Suraiyati R. "Rivers, Lakes, and Swamps: Sustainable Approach towards Ecotourism." Proceedings of the 3rd Regional Conference on Tourism Research. Langkawi, Malaysia (29-31 Oct, 2013).

[10] Picken, Felicity. "Beach Tourism." The SAGE International Encyclopedia of Travel and Tourism. 135-136. (March 2017). 